\title{
Drivers, Process, and Consequences of Native Grassland Degradation: Insights from a Literature Review and a Survey in Río de la Plata Grasslands
}

\author{
Guadalupe Tiscornia ${ }^{1, *(1)}$, Martín Jaurena ${ }^{2}$ and Walter Baethgen ${ }^{3}{ }^{(B)}$ \\ 1 Agro-Climate and Information System Unit (GRAS), National Institute of Agricultural Research (INIA \\ Uruguay), Ruta 48 KM.10, Canelones 90200, Uruguay \\ 2 Pastures and Forages National Research Program, National Institute of Agricultural Research (INIA \\ Uruguay), Ruta 5 KM.386, Tacuarembó 45000, Uruguay; mjaurena@inia.org.uy \\ 3 International Research Institute for Climate and Society (IRI), Columbia University, 61 Route 9W, Palisades, \\ NY 10964, USA; baethgen@iri.columbia.edu \\ * Correspondence: gtiscornia@inia.org.uy; Tel.: +598-2367-7641
}

Received: 23 March 2019; Accepted: 5 May 2019; Published: 10 May 2019

check for updates

\begin{abstract}
Natural grasslands are being progressively degraded around the world due to human-induced action (e.g., overgrazing), but there is neither a widely accepted conceptual framework to approach degradation studies nor a clear definition of what "grassland degradation" is. Most of the drivers, processes, and consequences related to grassland degradation are widespread and are usually separately quoted in the literature. In this paper, we propose a comprehensive framework with different conceptual categories, for monitoring grassland degradation, and a new definition based on current ones. We provide a conceptual update of grassland degradation based on a literature review and an expert survey, focused on the Río de la Plata grasslands (RPG). We identified "drivers" as external forces or changes that cause degradation; "processes" as measurable changes in grasslands conditions that can be evaluated using indicators; and "consequences" as the impacts or results of the process of grassland degradation. We expect that this conceptual framework will contribute to monitoring programs, to support management decisions, to design conservation measures, and to communicate the importance of grasslands conservation and the different concepts involved. Particularly for RPG, we expect that this paper will contribute to promote sustainable management practices in this important and often neglected ecosystem.
\end{abstract}

Keywords: productivity; forage; biomass; species diversity; indicators; grazing

\section{Introduction}

Grasslands cover an estimated area of $40 \%$ of the land surface [1]. There are different types of native grasslands, with communities determined mainly by climate and soil conditions, by grazing animals and by fire [2]. Globally, grasslands make a significant contribution to food security, providing forage for ruminants used for meat and milk production [3,4] and by the provision of many other important ecosystem services for human well-being $[5,6]$. However, the status of grasslands conservation varies around the world, but it is generally far from satisfactory [7]: they have shown signs of degradation, due primarily to overgrazing [2,8-12], other improper management practices [13-20], and climate change [12-14,16-18,20]. In fact, grasslands are among the ecosystems with the highest species richness in the world [21]. A global estimation of Gang et al. [17] showed that almost half of grassland ecosystems were degraded and almost $5 \%$ of these grasslands experiences strong to extreme levels of degradation. 
Given its relevance, grassland degradation has become an emerging topic in the fields of grassland management and environmental protection. Even though many authors and international organizations call for preservation of natural grasslands $[13,22,23]$, there is not a consensual definition of what natural grassland degradation is. The conceptual definitions of degradation are very broad, involving the deterioration of grassland quality, productivity, economic potential, service function, recovery ability, and diversity [24]. Others focus only on the decline of forage production or grassland productivity [9,25-28], and others incorporate invasion of non-native plant species [29,30], dominance of non-palatable species [31] or functions related to biogeochemical and water cycle [12,32-34]. In summary, the term "degradation" referring to the condition of a natural grassland, is widely used in different circumstances by different stakeholders, from researchers and rural extension agents, to policy makers, without a common agreed definition. These extremely variable definitions of grassland degradation reflect the wide variety of services expected from this ecosystem, with each definition corresponding to one or a few services.

Although definitions differ across human and environmental contexts, we argue that all of them can be grouped in conceptual categories related to degradation: e.g., drivers, process, or consequences. Many research reports focus on the process indicators of grassland degradation: e.g., Cao et al. [35] define the degradation as "an adverse reduction in biodiversity and biomass production, increased soil erosion, and nutrient loss". Wick et al. [15] in contrast, focus on consequences and define grassland degradation as the reduction in their ability to provide ecosystem goods and services. Other studies combine different conceptual categories, such as consequences and process indicators: "degradation ( ... ) leads to desertification, reduces grassland productivity and biodiversity" [36]; others combine drivers and process indicators: overgrazing, woody-plant encroachment, and invasion by non-native plant species, led to the reduction in the quantity or nutritional quality of the vegetation available for grazing" [29]. Clarifying these conceptual categories is crucial to build conceptual models that can explain the dynamics of grassland degradation and restoration.

Understanding the forces that drive the state of grasslands ecosystems, is an important first step for preventing their degradation. For this task, the State and Transition Model (STM) [37], simple diagrams that conceptualize the complex dynamic of the vegetation, which has been proposed as a useful tool to assess grassland management and conservation [38]. According to these models, there are "normal" or non-degraded vegetation states that are known to be very stable, since they rapidly return to its original condition after a small perturbation. However, discontinuous and irreversible changes (at least in the medium term) occur after a major disturbance, when the thresholds are exceeded and, a "normal" stable state is replaced by an alternative stable but unwanted (degraded) one [15,39]. It is frequently reported in the literature that primary driving forces of grassland degradation, which can be grouped into natural events (e.g., the increase in the frequency of extreme drought) and anthropogenic (management) factors (e.g., overgrazing or grazing abandonment) or by the interaction of both factors, can cause discontinuous changes in vegetation compositions that are non-reversible. These transitions to degraded communities are triggered when the driving forces overcome the resilience of the reference community $[40,41]$. However, the dividing line between what is considered "normal" and what is considered degraded is far from absolute.

Much has been studied about degradation in water-limited grasslands $[8,12,42-44]$, which are ecosystems very prone to soil desertification. In these grasslands, prolonged droughts and overgrazing are commonly recognized as the two common underlying drivers that lead to degradation. However, in mesic and humid grasslands, which are alternatively limited by temperature, water and nutrients, an in-depth synthesis of knowledge is needed to understand driving forces, process, and consequences of grassland degradation.

Given the importance and the need for preserving natural grasslands for livestock production and diversity, it is essential to reach a conceptual framework to study the process of grassland degradation. Considering de Quiroz [45] statement that degradation is intrinsically related to human management objectives, we believe that there is a need for a review of the studies conducted in grasslands used 
for livestock production. In this context, important questions arise: what is the condition of a degraded natural grassland? Which are the main drivers that influence grassland degradation? How ecological process are affected by grassland degradation? What are the main consequences of grassland degradation? The goal of this paper is to provide a conceptual update of grassland degradation based on an extensive worldwide literature review and an expert survey focused on the Río de la Plata region.

\section{Methodology}

\subsection{Literature Review}

A literature search was conducted in December 2016 with the main objectives of identifying the drivers, process indicators, and consequences related to degradation. We first used the free search engine Google Scholar (https://scholar.google.com/) to search across a wide range of academic sources and not only peer-reviewed literature. We searched by the terms "natural grassland degradation" and "rangeland degradation" related exclusively to livestock production; a complementary search in Spanish was conducted with the terms: "degradación", "campo natural" and "pastizales". Search in Portuguese was omitted, even though it is a very important language and the "Campos" region includes Brazil, due to the fact that in general the Brazilian journals have abstracts in English. Although there are many uses of natural grasslands such as recreation, hunting, and conservation, we address the issue of degradation of natural grassland, not of those intensively farmed.

A total of 5910 results were obtained: 5345 from the English-language search and another 565 from the Spanish-language search. Since we wanted to conduct an in-depth analysis of the concepts and indicators used to describe grassland degradation around the world, we limited our analysis to the most-cited 100 papers, though substitutions were made to ensure that at least one paper from each of the major grassland regions was represented (South American, North America, East Europe, Asia, Australia, and South Africa). Out of these 100 papers, we identified and systematized 27 papers that provided an explicit definition of grasslands degradation (see Supporting material in supplementary file).

Additionally, and to enrich and reinforce drivers, process indicators, and consequences and the conceptual framework, we updated the literature review by specifically searching in different scientific databases (Scopus, Science Direct, Springer, JSTOR, among others). As a result of this new search, an additional 40 papers were also systematized.

\subsection{Expert Survey}

To adapt our propose conceptual framework to the focus region, we center the expert survey on a regional level. We then conducted a regional survey focused on the Río de la Plata Grasslands (RPG).

This survey was first sent to the regional authors with more citations on "Río de la Plata Grasslands" research, and to take advantage of the expert network, we applied a "snowball sampling" technique [46]: we asked the experts to recommend three more people to whom the survey should be sent. This second group of experts was added to the expert list and surveys were sent to them as well. The survey was first conducted via email or phone, between July 2014 and March 2016.

The survey target population [47] consisted of 39 experts from different institutions: $54 \%$ from universities (Departments of Agronomy or Natural Sciences/Ecology), 13\% from the private sector (agronomic advisors and/or farmers), 33\% from other institutions (research institutes, extension institutes or the government, and non-profit organizations). The respondent's disciplinary backgrounds were $85 \%$ Grassland management scientists and 15\% Botany/Ecology. Only 8\% were women. In terms of nationality, 22 were Uruguayans, 11 Argentineans, and 6 Brazilians.

Five purposely open-ended questions were included in the survey: 1 . What do you consider to be a degraded natural grassland and how can you define it? 2. Mention three relevant indicators that you would use to characterize a degraded natural grassland. 3. How do you define a non-degraded natural grassland? 4. Mention three relevant indicators that you would use to characterize a non-degraded 
natural grassland. 5. Identify two or three of the most relevant characteristics that could be used to differentiate the two conditions.

\section{Conceptual Framework for Grassland Degradation}

In the present study, we established a framework that identified three distinct conceptual categories: drivers, processes, and consequences of natural grasslands degradation (Figure 1). For this work, we define "drivers" as the external forces or changes that can cause degradation, such as overgrazing or land use change. "Processes" are the conditions that create a sequence of changes in the properties of the grassland ecosystem, and can be evaluated using indicators, such as reduction in plant growth. We use the term "process indicator" as a variable used to measure and infer a conclusion from the phenomenon of degradation [48], such as vegetation height or bare ground cover. Finally, we consider "consequences" as the impacts or results of the process of grassland degradation, such as reduction in the Aboveground Net Primary Productivity (ANPP).

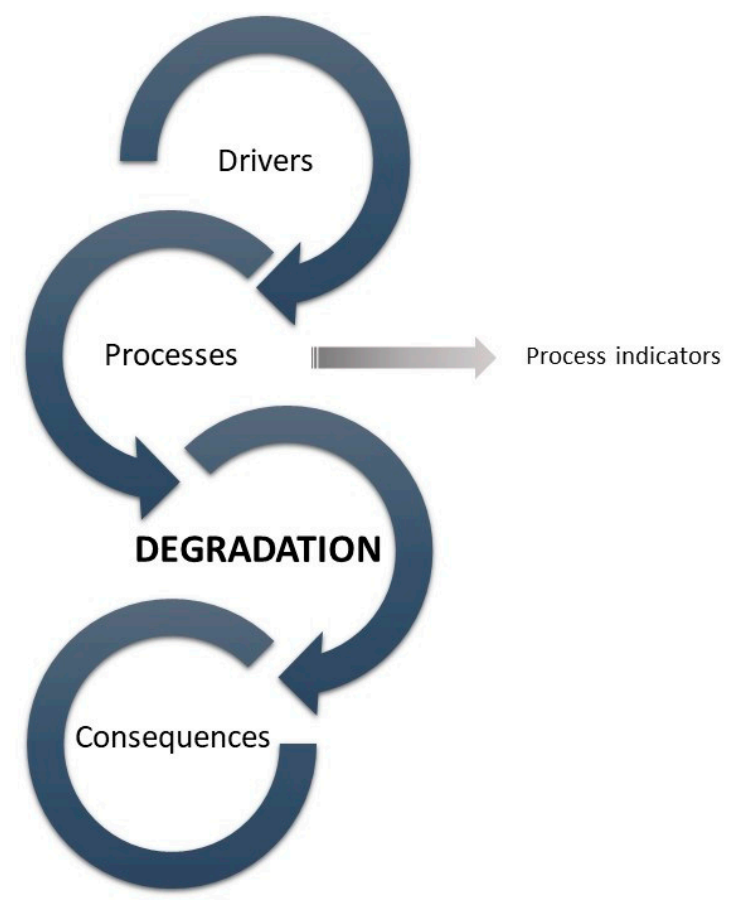

Figure 1. Conceptual framework of drivers, processes, and consequences of natural grasslands degradation.

\subsection{Which Are the Main Drivers that Influence Grassland Degradation?}

In Akiyama and Kawamura [9] review, they discussed several mechanisms of grassland degradation highlighting climate change and anthropogenic disturbances as the two main underlying factors that lead to degradation. Globally, the factors of climate change most related to grassland degradation are warming and the increase in the frequency of prolonged droughts $[13,16,17,33,35,49]$. Liu et al. [18], Gang et al. [17], Yang et al. [50], and Zhou et al. [20,51] presented quantitative assessments of the relative roles of climate change and anthropogenic perturbations, revealing that any of them can be the dominant driver of degradation depending on the study context. However, most of these studies did not consider the interactions between drivers. In this sense, Sala et al. [52] shows that there is clear evidence to support nonlinear responses of ecosystems and synergistic interactions among many global drivers of biodiversity change (e.g., invasions of alien species that are promoted by both human disturbances and climatic changes). On the other hand, Klein et al. [53] evince a decrease on ANPP and forage quality (for a of $1.0-2.0^{\circ} \mathrm{C}$ warming) but also showed an interaction with grazing that could mitigate that decline. Additionally, Carlyle et al. [54] analyzed different grasslands types 
and found, by manipulating temperature, water, and grazing conditions, that biomass production depends on the interaction between the three variables under site-specific conditions.

Overgrazing, which occurs when stocking rates exceed the carrying capacity of grasslands, is the most widespread anthropogenic driver of degradation $[9,55,56]$. In fact, stocking rates are less variable than the carrying capacity, and this is ultimately related to primary production and, therefore, to the climatic conditions. In this way, overgrazing clearly interacts with climate variability. In this regard, Liu et al. [18] report that Mongolian steppe degradation can be attributed both to climate change (decreasing precipitation and increasing temperature) and to the increase in the stocking rate. On the other hand, extreme under-grazing (or grazing abandonment) could also be a source of degradation affecting productivity and species composition. Although long term livestock exclosures increased standing biomass and vegetation cover, and they may be a useful management tool to restore the vegetation in degraded grassland of arid regions [57,58], they sometimes decreased grassland biodiversity [59,60] and ANPP [59].

Regarding grassland degradation, there is a long-standing controversy about the use of fire. On one hand, Snyman [61] suggested that fire may potentially degrade semiarid grassland based on the fact that the recovery of the above and below ground biomass production and water use efficiency, took at least two years after burning. On the other hand, the use of fire appears to be relevant in fire-prone communities (e.g., mesic grasslands) where fire is an evolutionary force that has been used for hundreds of years to maintain grassland structure and function [62].

Finally, the improper fertilization and/or exotic species introduction [63-65] and invasive alien species [66] are also other important factor influencing grassland degradation.

\subsection{How Ecological Process Are Affected by Grassland Degradation?}

\subsubsection{Energy Flux}

The most direct signs of grassland degradation are the change in vegetation parameters such as the decrease in litter mass, vegetation cover and height $[12,31,67,68]$. At the same time, the decline in vegetation vigor in degraded grasslands is also reflected in the decrease of the canopy leaf area index. This is highly relevant, since the leaf area index is one of the main controllers of the primary production through its role in the photosynthesis [69-71]. On the other hand, the decrease in vigor of the vegetation could be accompanied by the substitution of high forage quality species for low forage quality ones $[8,31,35,67]$. This species turnover could lead to a lower leaf area efficiency than non-degraded grasslands and, therefore, to a greater reduction in plant growth.

\subsubsection{Biogeochemical Cycles}

Grasslands have a high potential for carbon storage; however, this capacity strongly depends on how grasslands are managed [72]. The decrease in litter and plant cover in degraded grasslands can lead to a slowdown of the nutrient cycling $[67,73,74]$ and to a significant reduction of soil organic carbon [12,74-79] and nitrogen [80]. Additionally, the reduction in plant cover also results in a reduced infiltration, which in turn, increases soil erosion [81] and reduced soil water content [82]. This process can also slow down even more the nutrient cycling process via feedback cycles.

\subsubsection{Water Cycle}

The hydrological functioning of grasslands could change dramatically by the decrease in plant and litter cover. The decline in plant cover can lead to an increase in soil bulk density and a decline in the soil structural stability $[67,83,84]$. The degradation of grasslands increases evaporation rates $[85,86]$ and surface runoff $[83,87]$, reducing soil-water infiltration capacity $[67,83,84]$. This in turn reduces the effective soil water content [43] and increases soil loss due to erosion [88], leading to greater risks of degradation [89]. This process is highly relevant in semiarid regions, where plant and litter cover are scare per se. 


\subsection{What are the Main Consequences of Grassland Degradation?}

In countries with most of the territory occupied by grasslands and where extensive livestock production is an important economic activity, grassland degradation can cause significant economic and environmental problems. Some economic consequences arise, such as the decreased capacity to produce commodities $[24,45,90]$ (e.g., meat and wool). This occur because degraded grasslands have a decreased capacity to provide forage for livestock (e.g., decreased ANPP) $[8,18,24,26,35,55,91,92]$. In addition, in degraded grasslands, high forage quality species could be replaced by low productive species [8,31,35,67], with the consequent loss of forage nutritional value [31]. Such changes imply a reduction in the carrying capacity and, therefore, a reduction in livestock production $[9,56]$.

The degradation of the ecosystem services (benefits that society receives from ecosystems) involving water and nutrient cycle, energy flow, climate regulation, biodiversity and erosion control among others [6], has been repeatedly reported as one of the main consequences. Wen et al. [93] reported that primary production and other ecosystem services (carbon storage, nitrogen recycling, and plant diversity) of degraded grassland were always lower than those provided by non-degraded ones.

Changes in surface properties of the ecosystems, could severely affect the energy balance, which may affect the regional climate [94-96]. The decrease in litter quantity, vegetation height and biomass $[12,31,67,68]$; the replacement of high forage quality species by low quality ones $[8,31,35,67]$; the increase in runoff and soil losses [88]; and the decrease in litter [73], are key processes that, separately or together, can lead to a reduced plant growth which results in a lower secondary production.

Grassland degradation decrease soil organic carbon and nitrogen stocks and promote the emission of greenhouse gases into the atmosphere [12,80,93]. According to the two-year study of Zhang et al. [80], total carbon and nitrogen stored in a semiarid grassland ecosystem was reduced, under severe degradation conditions, by $16 \%$ and $10 \%$ respectively. Indeed, in a comprehensive meta-analysis Dlamini et al. [79] showed that grassland degradation reduced soil organic carbon by $16 \%$ and $8 \%$ in dry and wet climates, respectively. In some regions, degradation goes beyond its effects on ecosystem services, as it can lead to the completely loss of grassland habitat or to desertification [97].

Other important consequence of grassland degradation is the loss of animal and/or plant biodiversity $[24,35,65]$. Grazing usually increases species richness in mesic grasslands, while it generally reduces species richness in semiarid and arid grassland [98-100]. Even though there are some analysis as the one reported by Eldridge et al. [101], where grazing reduces ecosystem structure, function, and composition on different bioclimatic conditions (arid to humid and sub-humid) in Australia, the negative effects of grazing were greater in drier environments. Nevertheless, the way in which species decrease in overgrazed grasslands is mostly dependent on the grazing history and the position on the moisture gradient [102]. In mesic grasslands with long history of grazing, the peak of species richness generally occurs under moderate grazing intensities [102-104], meanwhile in sites with short history of grazing this peak happen at light grazing intensities. On the other hand, in semiarid grasslands with a long history of grazing, this peak take place at light grazing intensities, and then, as grazing intensity increases, species richness should decline slightly; meanwhile in sites with short history of grazing the species richness decrease linearly with the increase of grazing from non-grazed to severe grazing intensities [102,103].

\section{Conceptual Framework Adapted to RPG}

The South American RPG are one of the largest temperate and subtropical grasslands regions in the world. The RPG cover the central-eastern part of Argentina, most of Uruguay and southern Brazil [105] (Figure 2).

In the RPG, extensive livestock production has taken place for more than 300 years and therefore stocking rate management is a key factor for grassland conservation [106]. Specifically, the RPG have a predominance of C4 grasses, and C3 grasses to a lesser extent, and are the habitat of 4864 plant species [19]; 385 bird species and 90 mammal species [107]. 


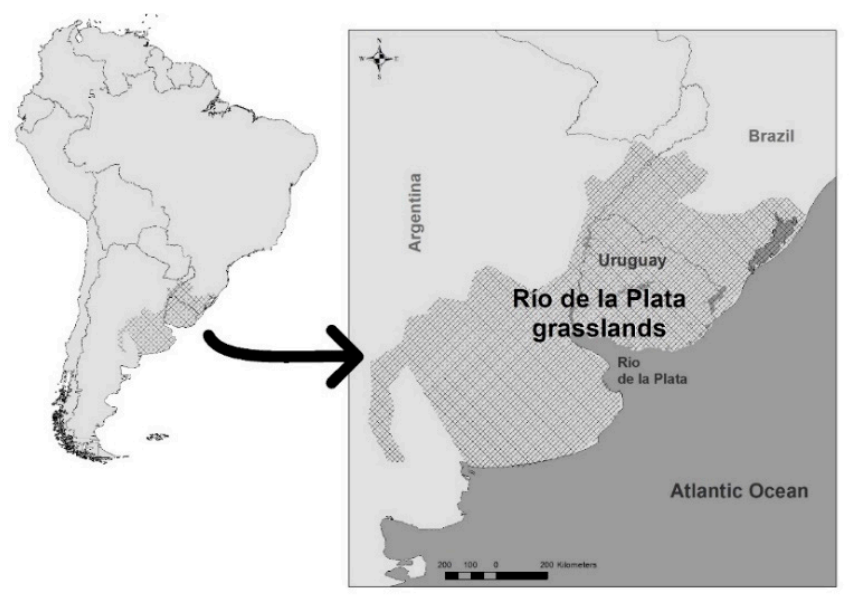

Figure 2. Map of South America highlighting the Río de la Plata grasslands region. Adapted from Miñarro and Bilenca [43].

Causes for degradation in RPG extensive livestock-based systems have been reported by many researchers, such as: (i) overgrazing by animals [56]; (ii) invasive alien species [108]; and (iii) nutrient addition and/or the introduction of exotic forage species into native grassland [63-65].

In RPG, animals graze all year round at relatively constant stocking rates [31], while ANPP of these grasslands shows large seasonal and inter-annual variations [109]. Under these conditions, grasslands can become recurrently overgrazed, mainly when periods of low forage production (e.g., severe droughts) coincide with high stocking rates. Indeed, the decreased forage biomass and the substitution of palatable species by unpalatable ones that can lead to a reduced plant growth and forage quality $[8,31]$ are some of the processes that most concern in RPG. Besides that, weed invasions $[108,110]$ and degradation promoted by fertilization and exotic forage species over-seeded in native grasslands are also concern. In these cases, the invasive weeds and the over-seeded species often weaken native species as they compete them for resources, such as space and light. However, as the over-seeded species do not persist, they end up facilitating the colonization and dominance of invasive species [65].

The consequences of overgrazing by livestock in RPG are strongly dependent on grassland type. Studies of Altesor et al. [59] in Southern Campos in Uruguay, Jaurena et al. [111] in northern Campos in Uruguay, and Fedrigo et al. [56] in Campos in Río Grande do Sul-Brazil indicate that these grasslands are particularly resistant to overgrazing. Meanwhile, in the Flooding Pampa in Argentina, the increase of grazing intensity induces a quick replacement of $\mathrm{C} 3$ and $\mathrm{C} 4$ native grasses by exotic annual forbs and grasses [112]. In addition, the most problematic invasive weed in the RPG is Eragrostis plana Nees, which has already invaded $20 \%$ of the native grassland in Río Grande do Sul, decreasing native plant diversity and livestock production [113].

\subsection{How Did Experts Percived the Degradation of Natural Grassland?}

According to the expert survey, in most cases, the experts recognized that the grassland degradation is strongly dependent on grassland community, related mainly to different soil types. They referred to degradation as a complex process that have diverse dynamics on each specific community or specific region. Most of the experts focused on the importance of the primary (plant) and secondary (animal) productivity. Some of grassland management specialist mentioned that the dominance of some exotic forage species, if they are palatable and nutritious for livestock, they did not consider the presence of these species (e.g., ryegrass Lolium multiflorum Lam.) to be an indicator of degradation. On the other hand, others defined the degradation problem related to the abiotic conditions that cause a change in the community state which is not reversible after the disturbance occurs. 


\subsection{Which Indicators Are the Most Important to Characterize Degradation?}

According to the conceptual framework previously described (Figure 1), we identified the drivers, process indicators, and consequences related to degradation from the literature review and experts survey. It is noteworthy that $63 \%$ of papers alluded to process indicators, $50 \%$ mentioned at least one driver, and $36 \%$ referred to consequences. The most commonly cited drivers ( $46 \%$ of the papers) were related to human-induced processes (mainly overgrazing). Loss of ecosystem processes, service and function $(24 \%)$ and soil erosion $(10 \%)$ were the most frequently declared consequences.

Half of the experts identified overgrazing in specific communities as the most mentioned driver. The most commonly cited consequences increased soil erosion (41\%) followed by reduction of resilience (including drought resistance) and the reduction of livestock production ( $28 \%$ each).

The most frequently mentioned indicators were vegetation or bare soil cover, productivity (ANPP related to the potential of the community), plant species or functional groups diversity, and species and functional type composition.

It is worth noticing that climate change was not considered to be an important driver for the experts but is was cited on the $15 \%$ pf the papers. Although drought resistance and resilience were mention as important consequences in the expert survey.

A comparison of the most relevant indicators extracted from the two different scales addressed in the study (regional and global) is shown in Table 1. 
Table 1. Frequency (\%) of the most relevant indicator mentioned in the literature review (from a total of 67 analyzed papers) and expert survey (from 29 experts who answered the survey). Some papers or experts mention more than one indicator. The " + " and " - " signs indicate the effect of the natural grassland's degradation on that indicator: a decrease (-) or an increase (+). Indicators are grouped following the conceptual framework present in Figure $1 .{ }^{*} 1$ (overgrazing, under-grazing, fragmentation); *2 (high forage value: quality and stability in time); *3 (related to livestock preference); 4 (mainly livestock production); 5 (water cycle, nutrient cycle, energy flow, species dynamic).

\begin{tabular}{|c|c|c|c|c|c|}
\hline Conceptual Category & Subtopic & Indicator & Effect & $\begin{array}{l}\% \text { of Papers } \\
\text { (Literature) }\end{array}$ & $\begin{array}{l}\text { \% of Experts } \\
\text { (Survey) }\end{array}$ \\
\hline \multirow{2}{*}{ Drivers } & & $\begin{array}{c}\text { Human-induced processes }{ }^{* 1} \\
{[6,8-10,13-16,25,29,34,35,52,55,56,63-65,91,92,106,114-122]}\end{array}$ & & 46 & 52 \\
\hline & & $\begin{array}{l}\text { Result of natural events (drought, climate change) } \\
{[13,14,16,17,25,33,35,49,55,115]}\end{array}$ & & 15 & \\
\hline \multirow{16}{*}{ Process indicators } & \multirow{6}{*}{ Productivity } & $\begin{array}{l}\text { Productivity (ANPP related to the potential in a specific soil type) } \\
{[12,15,24,25,29,32,34,36,45,55,90-92,115,123,124]}\end{array}$ & - & 24 & 55 \\
\hline & & $\begin{array}{c}\text { Vegetation and/or bare soil cover } \\
{[12,24,25,32,34,55,108,110,114,116,125-127]}\end{array}$ & - or + & 19 & 72 \\
\hline & & Productivity indicator species $\%{ }^{* 2}[4,123,124]$ & - & 4 & 45 \\
\hline & & Plant height $[12,92,125]$ & - & 4 & 31 \\
\hline & & Biomass or Forage availability $[9,10,14,35,55,92,115,126]$ & - & 12 & 7 \\
\hline & & Quality indicator species $(\%){ }^{* 3}[14,24,25,29,31,128]$ & - & 10 & 10 \\
\hline & \multirow{6}{*}{ Biodiversity } & $\begin{array}{l}\text { Plant species richness, plant or functional groups diversity } \\
\qquad[8,12,24,26,29,34,35,65,123,125]\end{array}$ & - & 15 & 55 \\
\hline & & Species and functional type composition $[8,29,115,123,126]$ & - or + & 7 & 55 \\
\hline & & Weeds (\%) [8] & + & 1 & 41 \\
\hline & & Structural heterogeneity [29] & - & 1 & 48 \\
\hline & & Non-native plant species $\%[65,108,110,127]$ & + & 6 & 41 \\
\hline & & Key, endemic or rare species [32] & - & 1 & 28 \\
\hline & \multirow{4}{*}{ Soil process } & Soil bulk density $[32,87]$ & + & 3 & 17 \\
\hline & & Soil organic matter $[32,74-78,92]$ & - & 10 & 14 \\
\hline & & Soil nutrients $[29,35,116]$ & + & 4 & 21 \\
\hline & & Litter presence $[67,68,73]$ & - & 4 & 10 \\
\hline
\end{tabular}


Table 1. Cont.

\begin{tabular}{|c|c|c|c|c|c|}
\hline Conceptual Category & Subtopic & Indicator & Effect & $\begin{array}{l}\% \text { of Papers } \\
\text { (Literature) }\end{array}$ & $\begin{array}{l}\% \text { of Experts } \\
\text { (Survey) }\end{array}$ \\
\hline \multirow{6}{*}{ Consequences } & & Soil erosion $[29,34,35,67,87,88,116]$ & + & 10 & 41 \\
\hline & & Drought resistance and resilience $[18,24,76,129]$ & - & 6 & 28 \\
\hline & & Secondary production ${ }^{* 4}[9,24,34,45,56,90,123,129]$ & - & 12 & 28 \\
\hline & & $\begin{array}{c}\text { Ecosystem processes, services and function *5 } \\
{[12,15,24,29,32,45,56,67,74,75,83,84,87,88,123,124]}\end{array}$ & - & 24 & 23 \\
\hline & & Plant health [15] & - & 1 & 21 \\
\hline & & Soil seed bank $[130,131]$ & - & 3 & 3 \\
\hline
\end{tabular}




\subsection{Conceptual Framework Proposed of Monitoring Río de la Plata Grassland Degradation}

According to the information discussed above, a complete conceptual framework diagram presenting the relation between those concepts is shown in Figure 3.

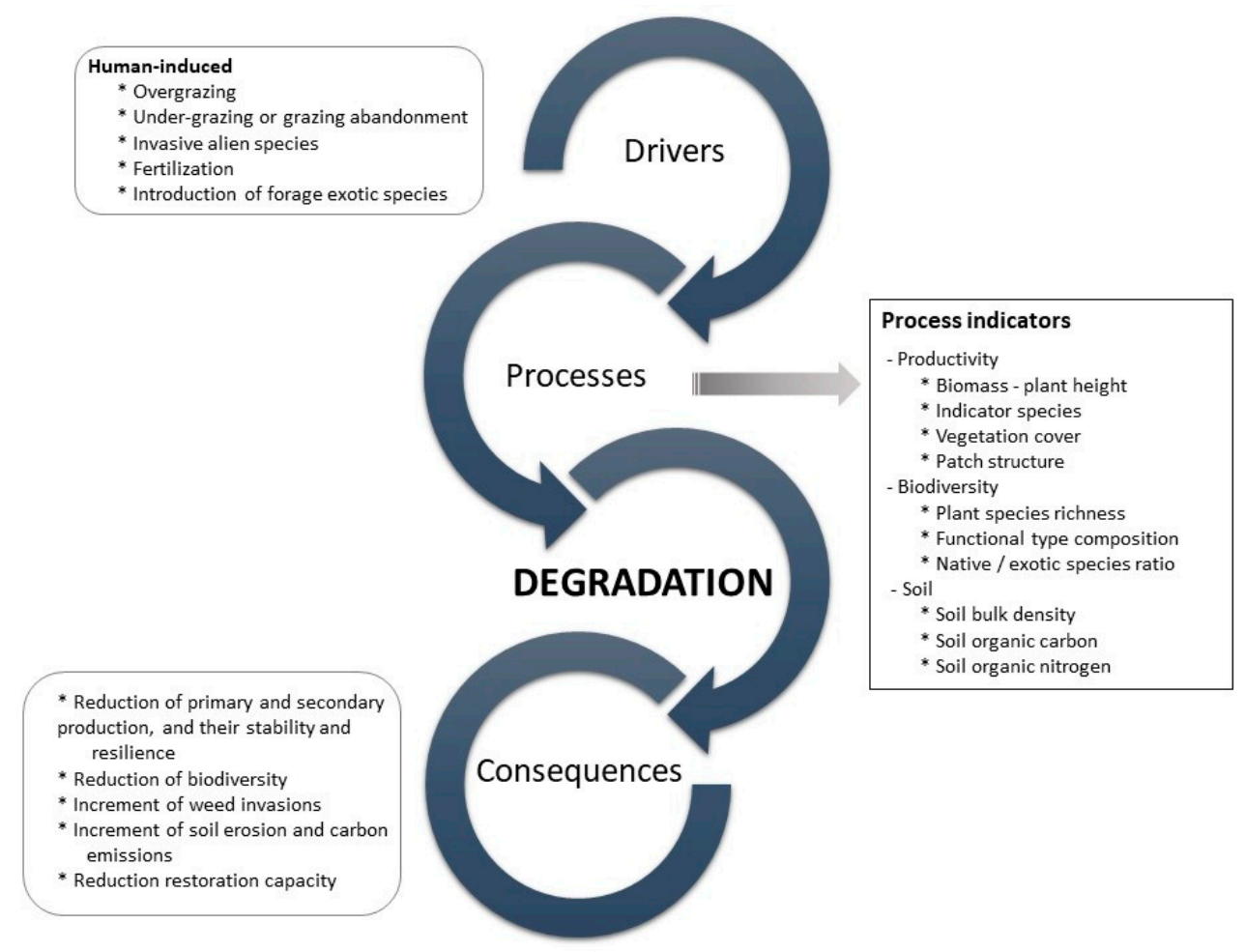

Figure 3. Proposed conceptual framework of RPG degradation with drivers, process indicators, and consequences based on literature review and expert survey.

\section{What is a Degraded Native Grassland?}

The term "degradation" referring to the condition of a natural grassland, is widely used in different circumstances by different stakeholders (from researchers and rural extension agents to policy makers), without a common agreed definition. Based on our review and considering that the interaction of grassland and herbivorous is the central key of the analysis, we propose as common definition of grassland degradation, a retro-progressive process in which a grassland community changes to a lower quality state, losing its capacity to be grazed by herbivores. Specifically, grassland degradation happens when you have a general decrease in productivity, soil properties, and diversity due to human activities and natural processes. This new definition is based on the fact that as plant communities degrade, above ground standing biomass and plant production decrease $[12,18,29,67,68]$, and soil-vegetation cover and litter amount decrease too $[67,74]$. These effects could occur in conjunction with changes in species composition $[8,29,35,67]$, reductions in species diversity $[24,35,65]$, increased soil erosion $[35,67,87,88]$ and augmented soil nutrient loss [67,74]; among other important effects. In all cases, different stakeholders agree that the degradation process leads to a lower quality of grassland ecosystem.

\section{Discussion}

The importance of natural grasslands to food security, to the provision of ecosystem services, and to the economy of many developing countries such as Uruguay, Argentina, and Brazil, imply that their degradation is a major political, economic, and environmental issue. This importance is reinforced by the experts' perception that degradation can be increased by the effects of livestock production intensification and climate change. Although it is widely known and repeatedly reported in the literature that overgrazing is one of the main global drivers of degradation, the experimental 
evidence of irreversible changes to degraded states in RPG is limited and it is highly dependent on the community type. The STMs developed in the RPG region by Andrade et al. [132] provide a conceptual framework of stages and thresholds that help researchers to study degradation and restoration. In the present review paper, we advance in the theoretical framework detailing the main drivers, process indicators, and consequences. Despite some differences evidence on the global literature review and the regional expert survey, some of the most frequently mentioned topics were the same, and they have some common process indicators, suggesting that the problem of degradation may have a common interpretation. Taking this into consideration, grassland degradation for livestock production could be monitored assessing drivers, process indicators, and consequences as in the propose framework.

From our perspective, to further advance in the knowledge of grassland degradation process in RPG, we represent the interactive effects of rainfall variability and overgrazing, in new conceptual STMs (Figure 4A-D). Specifically, to support the decisions of ecosystem management, these models try to link (i) multiple drivers operating simultaneously, in different site-specific conditions (e.g., soil types bioclimatic zones and evolutionary history of grazing), (ii) the main process affected (e.g., decreased on primary production by a reduced of the leaf area index, or the reduction on plant species diversity by an increment on interspecific competitive exclusion for light) and its indicators, and (iii) the expected consequences of management practices in different climatic scenarios.
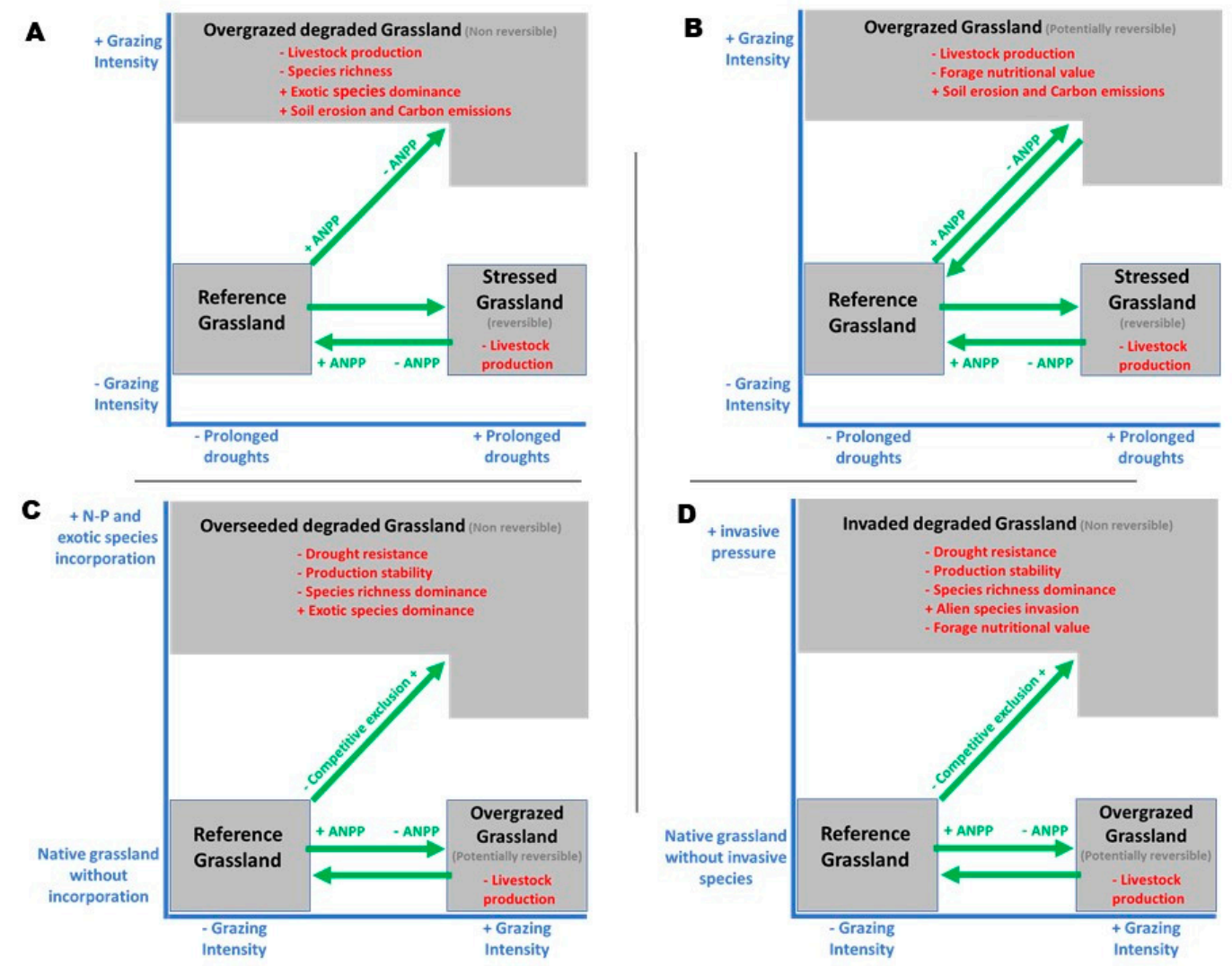

Figure 4. Conceptual framework proposed for the study of grassland degradation in the RPG represented by four state and transition models: (A) Grassland degradation by overgrazing and increased rainfall variability in sites with short evolutionary history of grazing; (B) Grassland degradation by overgrazing and increased rainfall variability in sites with long evolutionary history of grazing; (C) Grassland degradation by intensification (nitrogen and phosphorous incorporation combined with over-seeding of exotic forage species) with different grazing intensities; and (D) Grassland degradation by invasive alien species with different grazing intensities. Drivers are remarked in blue, process in green and consequences in red. ANPP (above ground net primary production). The two-sided arrows represent potentially reversible processes when the disturbance is removed, while the one-sided arrows represent an irreversible shift to a degraded state. 
Some studies conducted in the Flooding Pampas in Argentina [112,133] reveal that grazing would induce rapid changes to alternative degraded states (Figure 4A). However, on the other hand, studies carried out on Campos grasslands $[56,134]$ suggest that grazing intensity and climate variability would induce phase changes within states (slow, continuous and reversible community changes), but would not cause change into alternative degraded stable states (Figure 4B). Similar results are reported by Porensky et al., [135] in northern mixed-grass prairie in the USA. The differences in responses of plant community to overgrazing, which experts mentioned repeatedly, could be related with the interaction between grassland bioclimatic conditions and the evolutive history of grazing [103]. However, there is a lack of knowledge in that history on a specific region with an adequate spatial-temporal resolution, this has repercussions in being able to capture grassland dynamics (essential to understand short term evolution). To overcome this limitation, Oesterheld and Semmartin [136] propose to consider the regional set of species, the covariation of production and grazing intensity, and the positive biotic interactions that protect plants from herbivores, for a better understanding of why different grasslands communities respond differently to grazing. Additionally, invasive alien species [108] and nutrient addition and/or the introduction of exotic forage species into native grasslands [63-65] in interaction with grazing intensity would induce changes to alternative degraded states (Figure 4C,D).

As we already mentioned, grassland degradation has become a widespread and common problem in different regions of the world and in this review paper we have found that different regions and grassland types have some common drivers, process, and consequences related to degradation and thus, have the potential to be analyzed and monitored by a common framework. However, the reviewed articles also revealed that other drivers, processes and consequences were common within a similar rainfall variability conditions, and different according to a bioclimatic gradient and evolutive history of grazing. Climate change appears to be a significant driver on arid grasslands $[20,50,51,137]$ while it is not mentioned in humidity grasslands analysis. On the other hand, light grazing intensity or grazing exclusion, have different effects depending on the bioclimatic region, with a positive effect on arid environments [57,58], and a negative one on humidity regions [59,60]. Regarding consequences, desertification is exclusively reported on arid and semiarid areas [9].

Although it seems that the responses to the underlying drivers of degradation are different between semiarid, mesic, and humid grasslands, we suggest that this bioclimatic gradient mask the true effect of rainfall variability. The results of Davidowitz [138] showed that more drier grasslands generally are climatically more variable than the humid ones, so inter-annual rainfall variability is inversely related to its mean. For many processes, inter-annual rainfall variability can be a more important climatic parameter than the average precipitations [139]. For instance, where rainfall variability is high in relation to its average, species need to adapt to first survive prolonged drought periods and then, to take advantage of long rainfall periods [140]. Additionally, in arid and semiarid rangelands, the variability in ANPP could be higher than variability in rainfall [141,142].

Although several studies quantified the effects of climate change and anthropogenic management on grassland degradation, simulating actual vs. potential net primary production effects $[17,20,50,51,135]$, their interactions have not been addressed and the effect of frequency and intensity increment of extreme precipitation events on grassland degradation, remains almost unexplored.

In this review, we found that most of grassland degradation studies were conducted in water-limited grasslands. In these grasslands, prolonged droughts and overgrazing are the two common underlying drivers that lead to degradation. Sloat et al. [143] found that grasslands regions with high rainfall variability support lower livestock densities than less-variable areas. Considering that stocking rates are less variable than the carrying capacity and therefore than climatic conditions, overgrazing clearly interacts with the increased rainfall variability. From these non-equilibrium concept of grassland dynamics proposed by Ellis and Swift [144], it has been predicted that the potential degradation by overgrazing is low in environments with relatively high rainfall variability. These studies argue that in periods of drought, herbivores population is reduced, thereby decreasing their potential to degrade grasslands. We consider that this application of the non-equilibrium concept could contribute to 
understand the dynamic of wildlife-based ecosystems where animals self-regulate their populations during prolonged droughts. However, this is not the general case in extensive livestock-based systems where farmers seek to maximize profit. In this context, farmers have two contrasting scenarios for the application of management practices to mitigate drought effects. On one hand, they could provide supplemental emergency feed (e.g., crop residues or grain by-products), use stockpile forage and facilitate the access to water sources to minimize animal mortality and to avoid weight losses in drought periods, maintaining the stocking rates. This managements practices could lead to a positive feedback that cause further degradation [145]. As a second option, if these same management options are combined with the reduction of the stocking rate to match availability of lower forage and to minimizes the effect of grazing on vegetation, a negative feedback could probably occur that will prevent degradation.

The diversity of grasslands, the differential impacts of climate and management on them, and the variety of uses and human dimensions throughout the world, are the main reasons for the coexistence of different conceptual significances of degradation. de Queiroz [45] state that definitions of degradation are different depending on the human management objectives. Given that these objectives can differ, the definitions of what constitutes degradation also differ. We argue that definitions can also differ due to emphasis on different conceptual categories related to degradation and that is why it is important of clarify these conceptual categories. Moreover, the concept of degradation does not denote the same set of conditions for different stakeholders. Bedunah and Angerer [5] highlighted the complexity of the term degradation by claiming that rangeland scientists need to have a key role in collecting, understanding, and commenting on degradation definitions used by stakeholders. Agreeing on a definition of a complex concept such as grassland degradation is also important for research purposes, since it contributes to identify what processes need to be described and which variables need to be measured to systematically assess the degree of degradation.

\section{Conclusions}

Grassland degradation has multicausal drivers; however, the complexity of this process remains mostly unexplored, since most of the studies focus on single drivers of vegetation change. From our study, we proposed a new conceptual model which consider the multiple drivers that operate simultaneously and their interactions in different site-specific conditions.

Despite the difference in scale (global and regional), some of the mentioned topics were the same and they have some common process indicators suggesting that the problem of degradation, may have a common interpretation and can be analyzed with a common conceptual framework.

We believe that the proposed conceptual framework for the degradation of grasslands used for livestock production is a valuable contribution to monitoring programs and to support grassland management decisions, by clarifying the different concepts involved in the process (drivers, process indicators, and consequences) and structuring the degradation analysis allowing identifying key aspects. In addition, the framework could be a useful tool to communicate the importance of grasslands conservation, both to a general audience and to specialists in the field.

Despite this, we also found that some drivers, process, and consequences were common within a bioclimatic zone and could be different along a bioclimatic gradient. This gives some particularities to the systems that needs to be abroad and could be also analyzed according to the proposed conceptual framework.

Considering the RPG region, we expect that this paper will contribute to reach a conceptual update of grassland degradation based on the mentioned concepts that can help to promote a dual goal of production and conservation in this important and often neglected ecosystem.

Supplementary Materials: The following are available online at http://www.mdpi.com/2073-4395/9/5/239/s1, supplementary file: Supporting Literature review.pdf. 
Funding: This research has been conducted as part of a Ph.D. program (Facultad de Agronomía, Universidad de la República, Uruguay) supported by the Agro-climate and Information System Unit (GRAS) of the National Agricultural Research Institute (INIA Uruguay) and a partial scholarship provided by the National Agency for Research and Innovation (ANII Uruguay).

Acknowledgments: We want to especially thank the experts who took the time to answer the questions or discussed the topic. We also want to thank Cathy Vaughan from IRI (International Research Institute for Climate and Society Columbia University) and Andrea Ruggia from INIA (National Institute of Agricultural Research, Uruguay) for their comments, reviews, and contributions. Finally, a special mention to Valentín Picasso from the Agronomy Department, University of Wisconsin for his great contribution to this paper.

Conflicts of Interest: The authors declare no conflict of interest.

\section{References}

1. Gibson, D.J. Grasses and Grassland Ecology; Oxford University Press: Oxford, UK, 2009; p. 313.

2. Allen, V.G.; Batello, C.; Berretta, E.J.; Hodgson, J.; Kothmann, M.; Li, X.; McIvor, J.; Milne, J.; Morris, C.; Peeters, A.; et al. An international terminology for grazing lands and grazing animals. Grass Forage Sci. 2011, 66, 2-28. [CrossRef]

3. Lund, H.G. Accounting for the world's rangelands. Rangelands 2007, 29, 3-10. [CrossRef]

4. O'Mara, F.P. The role of grasslands in food security and climate change. Review: Part of a highlight on breeding strategies for forage and grass improvement. Ann. Bot. 2012, 110, 1263-1270. [CrossRef] [PubMed]

5. Bedunah, D.J.; Angerer, J.P. Rangeland degradation, poverty, and conflict: How can rangeland scientists contribute to effective responses and solutions? Rangel. Ecol. Manag. 2012, 65, 606-612. [CrossRef]

6. Modernel, P.; Rossing, W.A.H.; Corbeels, M.; Dogliotti, S.; Picasso, V.; Tittonell, P. Land use change and ecosystem service provision in Pampas and Campos grasslands of southern South America. Environ. Res. Lett. 2016, 11, 113002. [CrossRef]

7. Suttie, J.M.; Reynolds, S.G.; Batello, C. Grasslands of the World; Food and Agriculture Organization of the United Nations: Rome, Italy, 2005; p. 535.

8. Berretta, E.J.; Risso, D.F.; Montossi, F.; Pigurina, G. Campos in Uruguay. In Grassland Ecophysiology and Grazing Ecology; Lemaire, G., Hodgson, J., de Moraes, A., Nabinger, C., Carvalho, P.C., Eds.; CABI Publishing: New York, NY, USA, 2000; Volume 19, pp. 377-394.

9. Akiyama, T.; Kawamura, K. Grassland degradation in China: Methods of monitoring, management and restoration. Jpn. Soc. Grassl. Sci. 2007, 53, 1-17. [CrossRef]

10. Wessels, K.J.; Prince, S.D.; Carroll, M.; Malherbe, J. Relevance of rangeland degradation in semiarid northeastern South Africa to the non-equilibrium theory. Ecol. Appl. 2007, 17, 815-827. [CrossRef]

11. Harris, R.B. Rangeland degradation on the Qinghai-Tibetan plateau: A review of the evidence of its magnitude and causes. J. Arid Environ. 2010, 74, 1-12. [CrossRef]

12. Han, J.G.; Zhang, Y.J.; Wang, C.J.; Bai, W.M.; Wang, Y.R.; Han, G.D.; Li, L.H. Rangeland degradation and restoration management in China. Rangel. J. 2008, 30, 233-239. [CrossRef]

13. Veldman, J.W.; Buisson, E.; Durigan, G.; Fernandes, G.W.; Le Stradic, S.; Mahy, G.; Negreiros, D.; Overbeck, G.E.; Veldman, R.G.; Zaloumis, N.P.; et al. Toward an old-growth concept for grasslands, savannas, and woodlands. Front. Ecol. Environ. 2015, 13, 154-162. [CrossRef]

14. Mansour, K.; Mutanga, O.; Everson, T. Remote sensing based indicators of vegetation species for assessing rangeland degradation: Opportunities and challenges. Afr. J. Agric. Res. 2012, 7, 3261-3270.

15. Wick, A.F.; Geaumont, B.A.; Sedivec, K.; Hendrickson, J. Grassland degradation. In Biological and Environmental Hazards, Risks and Disasters; Shroder, J.F., Sivanpillai, R., Eds.; Elsevier: New York, NY, USA, 2016; Volume 8, pp. 257-276. ISBN 9780123964717.

16. Zhou, H.; Zhao, X.; Tang, Y.; Gu, S.; Zhou, L. Alpine grassland degradation and its control in the source region of the Yangtze and Yellow Rivers, China. Grassl. Sci. 2005, 51, 191-203. [CrossRef]

17. Gang, C.; Zhou, W.; Chen, Y.; Wang, Z.; Sun, Z.; Li, J.; Qi, J.; Odeh, I. Quantitative assessment of the contributions of climate change and human activities on global grassland degradation. Environ. Earth Sci. 2014, 72, 4273-4282. [CrossRef]

18. Liu, Y.Y.; Evans, J.P.; McCabe, M.F.; de Jeu, R.A.M.; van Dijk, A.I.J.M.; Dolman, A.J.; Saizen, I. Changing Climate and Overgrazing Are Decimating Mongolian Steppes. PLoS ONE 2013, 8, e57599. [CrossRef] 
19. Andrade, B.O.; Marchesi, E.; Burkart, S.; Setubal, R.B.; Lezama, F.; Perelman, S.; Schneider, A.A.; Trevisan, R.; Overbeck, G.E.; Boldrini, I.I. Vascular plant species richness and distribution in the Río de la Plata grasslands. Bot. J. Linn. Soc. 2018, 188, 250-256. [CrossRef]

20. Zhou, W.; Gang, C.; Zhou, L.; Chen, Y.; Li, J.; Ju, W.; Odeh, I. Dynamic of grassland vegetation degradation and its quantitative assessment in the northwest China. Acta Oecol. 2014, 55, 86-96. [CrossRef]

21. Wilson, J.B.; Peet, R.K.; Dengler, J.; Pärtel, M. Plant species richness: The world records. J. Veg. Sci. 2012, 23, 796-802. [CrossRef]

22. Henwood, W.D. Editorial-the world's temperate grasslands: A beleaguered biome. Parks 1998, 8, 1-2.

23. Carvalho, P.C.; Batello, C. Access to land, livestock production and ecosystem conservation in the Brazilian Campos biome: The natural grasslands dilemma. Livest. Sci. 2009, 120, 158-162. [CrossRef]

24. Xu, X.; Liu, J.; Shao, Q. Spatial and temporal characteristics of grassland degradation in the riverhead area of the Yellow River. In Second International Conference on Earth Observation for Global Changes; International Society for Optics and Photonics: Bellingham, WA, USA, 2009; Volume 7471, pp. 74710R-1-74710R-7.

25. Manssour, K. Rangeland Degradation Assessment Using Remote Sensing and Vegetation Species. Ph.D. Thesis, Faculty of Science and Agriculture, University of KwaZulu-Natal, Durban, South Africa, 2011.

26. Liu, Y.; Zha, Y.; Gao, J.; Ni, S. Assessment of grassland degradation near Lake Qinghai, West Chine, using Landsat TM and in situ reflectance spectra data. Int. J. Remote Sens. 2004, 25, 4177-4189. [CrossRef]

27. Rosengurtt, B. Estudios Sobre Praderas Naturales del Uruguay $3^{a}$ Contribución; Barreiro y Ramos: Montevideo, Uruguay, 1943; p. 281.

28. Berretta, E.J.; do Nascimento, D., Jr. Glosario Estructurado de Términos Sobre Pasturas y Producción Animal; Diálogo 32; IICA-PROCISUR: Montevideo, Uruguay, 1991; p. 127. ISBN 92-9039-180-4.

29. Behmanesh, B.; Barani, H.; Sarvestani, A.A.; Shahraki, M.R.; Sharafatmandrad, M. Rangeland degradation assessment: A new strategy based on indigenous ecological knowledge of pastoralists. Solid Earth Discuss. 2015, 7, 2999-3019. [CrossRef]

30. Millot, J.C.; Methol, R.; Risso, D. Relevamiento de Pasturas Naturales y Mejoramientos Extensivos en Áreas Ganaderas del Uruguay: Informe Técnico de la Comisión Honoraria del Plan Agropecuario; Consultora F.U.C.R.E.A; MGAP: Montevideo, Uruguay, 1987; p. 199.

31. Pallarés, O.R.; Berretta, E.J.; Maraschin, G.E. The South American campos ecosystem. In Grasslands of the World; Suttie, J., Reynolds, S.G., Batello, C., Eds.; FAO: Roman, Italy, 2005; pp. 171-219.

32. Tácuna, R.E.; Aguirre, L.; Flores, E.R. Influencia de la revegetación con especies nativas y la incorporación de materia orgánica en la recuperación de pastizales degradados. Ecol. Appl. 2015, 14, 191-200. [CrossRef]

33. Wang, Z.; Deng, X.; Song, W.; Li, Z.; Chen, J. What is the main cause of grassland degradation? A case study of grassland ecosystem service in the middle-south Inner Mongolia. Catena 2017, 150, 100-107. [CrossRef]

34. Abdalla, K.; Mutema, M.; Chivenge, P.; Everson, C.; Chaplot, V. Grassland degradation significantly enhances soil $\mathrm{CO}_{2}$ emission. Catena 2018, 167, 284-292. [CrossRef]

35. Cao, J.; Yeh, E.T.; Holden, N.M.; Qin, Y.; Ren, Z. The roles of overgrazing, climate change and policy as drivers of degradation of China's grasslands. Nomadic Peoples 2013, 17, 82-101. [CrossRef]

36. Li, S.; Verburg, P.H.; Lv, S.; Wu, J.; Li, X. Spatial analysis of the driving factors of grassland degradation under conditions of climate change and intensive use in Inner Mongolia, China. Reg. Environ. Chang. 2012, 12, 461-474.

37. Westoby, M.; Walker, B.; Noy-Meir, I. Opportunistic management for rangelands not at equilibrium. J. Range Manag. 1989, 42, 266-274. [CrossRef]

38. Briske, D.D.; Fuhlendorf, S.D.; Smeins, F.E. State-and-transition models, thresholds, and rangeland health: A synthesis of ecological concepts and perspectives. Rangel. Ecol. Manag. 2005, 58, 1-10. [CrossRef]

39. Lopez, D.R.; Cavallero, L.; Brizuela, M.A.; Aguiar, M.R. Ecosystemic structural-functional approach of the state and transition model. Appl. Veg. Sci. 2011, 14, 6-16. [CrossRef]

40. Briske, D.D.; Fuhlendorf, S.D.; Smeins, F.E. A unified framework for assessment and application of ecological thresholds. Rangel. Ecol. Manag. 2006, 59, 225-236. [CrossRef]

41. Briske, D.D.; Bestelmeyer, B.T.; Stringham, T.K.; Shaver, P.L. Recommendations for development of resilience-based state-and-transition models. Rangel. Ecol. Manag. 2008, 61, 359-367. [CrossRef]

42. Snyman, H.A. Rangeland degradation in a semi-arid South Africa-I: Influence on seasonal root distribution, root/shoot ratios and water-use efficiency. J. Arid Environ. 2005, 60, 457-481. [CrossRef] 
43. Snyman, H.A.; Du Preez, C.C. Rangeland degradation in a semi-arid South Africa-II: Influence on soil quality. J. Arid Environ. 2005, 60, 483-507. [CrossRef]

44. Cai, H.; Yang, X.; Xu, X. Human-induced grassland degradation/restoration in the central Tibetan Plateau: The effects of ecological protection and restoration projects. Ecol. Eng. 2015, 83, 112-119. [CrossRef]

45. de Queiroz, J.S. Range Degradation in Botswana; Pastoral Development Network Paper, No. 35b; Overseas Development Institute (ODI): London, UK, 1993; p. 19.

46. Atkinson, R.; Flint, J. Accessing hidden and hard-to-reach populations: Snowball research strategies. Soc. Res. Update 2001, 33, 1-4.

47. Vogt, W.P.; Johnson, R.B. Dictionary of Statistics E Methodology: A Nontechnical Guide for the Social Sciences: A Nontechnical Guide for the Social Sciences; Sage Publications: Thousand Oaks, CA, USA, 2011; p. 437.

48. Heink, U.; Kowarik, I. What are indicators? On the definition of indicators in ecology and environmental planning. Ecol. Indic. 2010, 10, 584-593. [CrossRef]

49. Chen, B.; Zhang, X.; Tao, J.; Wu, J.; Wang, J.; Shi, P.; Zhang, Y.; Yu, C. The impact of climate change and anthropogenic activities on alpine grassland over the Qinghai-Tibet Plateau. Agric. For. Meteorol. 2014, 189, 11-18. [CrossRef]

50. Yang, Y.; Wang, Z.; Li, J.; Gang, C.; Zhang, Y.; Zhang, Y.; Oden, I.; Qi, J. Comparative assessment of grassland degradation dynamics in response to climate variation and human activities in China, Mongolia, Pakistan and Uzbekistan from 2000 to 2013. J. Arid Environ. 2016, 135, 164-172. [CrossRef]

51. Zhou, W.; Yang, H.; Huang, L.; Chen, C.; Lin, X.; Hu, Z.; Li, J. Grassland degradation remote sensing monitoring and driving factors quantitative assessment in China from 1982 to 2010. Ecol. Indic. 2017, 83, 303-313. [CrossRef]

52. Sala, O.E.; Chapin, F.S.; Armesto, J.J.; Berlow, E.; Bloomfield, J.; Dirzo, R.; Huber-Sanwald, E.; Huenneke, L.F.; Jackson, R.B.; Kinzig, A.; et al. Global biodiversity scenarios for the year 2100. Science 2000, 287, 1770-1774. [CrossRef]

53. Klein, J.A.; Harte, J.; Zhao, X.Q. Experimental warming, not grazing, decreases rangeland quality on the Tibetan Plateau. Ecol. Appl. 2007, 17, 541-557. [CrossRef]

54. Carlyle, C.N.; Fraser, L.H.; Turkington, R. Response of grassland biomass production to simulated climate change and clipping along an elevation gradient. Oecologia 2014, 174, 1065-1073. [CrossRef] [PubMed]

55. Yao, Z.; Zhao, C.; Yang, K.; Liu, W.; Li, Y.; You, J.; Xiao, J. Alpine grassland degradation in the Qilian Mountains, China-A case study in Damaying Grassland. Catena 2016, 137, 494-500. [CrossRef]

56. Fedrigo, J.K.; Ataide, P.F.; Filho, J.A.; Oliveira, L.V.; Jaurena, M.; Laca, E.A.; Overbeck, G.E.; Nabinger, C. Temporary grazing exclusion promotes rapid recovery of species richness and productivity in a long-term overgrazed Campos grassland. Restor. Ecol. 2017, 26, 677-685. [CrossRef]

57. Al-Rowaily, S.L.; El-Bana, M.I.; Al-Bakre, D.A.; Assaeed, A.M.; Hegazy, A.K.; Ali, M.B. Effects of open grazing and livestock exclusion on floristic composition and diversity in natural ecosystem of Western Saudi Arabia. Saudi J. Biol. Sci. 2015, 22, 430-437. [CrossRef] [PubMed]

58. Qasim, S.; Gul, S.; Shah, M.H.; Hussain, F.; Ahmad, S.; Islam, M.; Rehman, G.; Yaqoob, M.; Shah, S.Q. Influence of grazing exclosure on vegetation biomass and soil quality. Int. Soil Water Conserv. Res. 2017, 5, 62-68. [CrossRef]

59. Altesor, A.; Oesterheld, M.; Leoni, E.; Lezama, F.; Rodríguez, C. Effect of grazing on community structure and productivity of a Uruguayan grassland. Plant Ecol. 2005, 179, 83-91. [CrossRef]

60. Yao, X.; Wu, J.; Gong, X.; Lang, X.; Wang, C. Grazing exclosures solely are not the best methods for sustaining alpine grasslands. PeerJ 2019, 7, e6462. [CrossRef]

61. Snyman, H.A. Short-term responses of southern African semi-arid rangelands to fire: A review of impact on soils. Arid Land Res. Manag. 2015, 29, 222-236. [CrossRef]

62. Bond, W.J.; Keeley, J.E. Fire as a global 'herbivore': The ecology and evolution of flammable ecosystems. Trends Ecol. Evol. 2005, 20, 387-394. [CrossRef] [PubMed]

63. Brambilla, D.M.; Nabinger, C.; Kunrath, T.R.; Carvalho, P.C.D.F.; Carassai, I.J.; Cadenazzi, M. Impact of nitrogen fertilization on the forage characteristics and beef calf performance on native pasture overseeded with ryegrass. Rev. Bras. Zootec. 2012, 41, 528-536. [CrossRef]

64. de Ávila, M.R.; Nabinger, C.; Brambilla, D.M.; Carassai, I.J.; Kunrath, T.R. The effects of nitrogen enrichment on tiller population density and demographics of annual ryegrass overseeded on natural pastures South of Brazil. Afr. J. Agric. Res. 2013, 8, 3013-3018. 
65. Jaurena, M.; Lezama, F.; Salvo, L.; Cardozo, G.; Ayala, W.; Terra, J.; Nabinger, C. The dilemma of improving native grasslands by overseeding legumes: Production intensification or diversity conservation. Rangel. Ecol. Manag. 2016, 69, 35-42. [CrossRef]

66. Stohlgren, T.J.; Binkley, D.; Chong, G.W.; Kalkhan, M.A.; Schell, L.D.; Bull, K.A.; Otsuki, Y.; Newman, G.; Bashkin, M.; Son, Y. Exotic plant species invade hot spots of native plant diversity. Ecol. Monogr. 1999, 69, 25-46. [CrossRef]

67. Li, C.; Hao, X.; Zhao, M.; Han, G.; Willms, W.D. Influence of historic sheep grazing on vegetation and soil properties of a Desert Steppe in Inner Mongolia. Agric. Ecosyst. Environ. 2008, 128, 109-116. [CrossRef]

68. Yan, L.; Zhou, G.; Zhang, F. Effects of Different Grazing Intensities on Grassland Production in China: A Meta-Analysis. PLoS ONE 2013, 8, e81466. [CrossRef]

69. Bircham, J.S.; Hodgson, J. The influence of sward condition on rates of herbage growth and senescence in mixed swards under continuous stocking management. Grass Forage Sci. 1983, 38, 323-331. [CrossRef]

70. Asner, G.P.; Scurlock, J.M.O.; Hicke, J.A. Global synthesis of leaf area index observations: Implications for ecological and remote sensing studies. Glob. Ecol. Biogeogr. 2003, 12, 191-205. [CrossRef]

71. Sbrissia, A.F.; Duchini, P.G.; Zanini, G.D.; Santos, G.T.; Padilha, D.A.; Schmitt, D. Defoliation Strategies in Pastures Submitted to Intermittent Stocking Method: Underlying Mechanisms Buffering Forage Accumulation over a Range of Grazing Heights. Crop Sci. 2018, 58, 945-954. [CrossRef]

72. McSherry, M.E.; Ritchie, M.E. Effects of grazing on grassland soil carbon: A global review. Glob. Chang. Biol. 2013, 19, 1347-1357.

73. Willms, W.D.; Smoliak, S.; Bailey, A.W. Herbage production following litter removal on Alberta native grasslands. J. Range Manag. 1986, 39, 536-540. [CrossRef]

74. Liu, N.; Zhang, Y.; Chang, S.; Kan, H.; Lin, L. Impact of Grazing on Soil Carbon and Microbial Biomass in Typical Steppe and Desert Steppe of Inner Mongolia. PLoS ONE 2012, 7, e36434. [CrossRef]

75. Zhang, R.; Bai, Y.; Zhang, T.; Henkin, Z.; Degen, A.A.; Jia, T.; Guo, C.; Long, R.; Shang, Z. Driving Factors That Reduce Soil Carbon, Sugar, and Microbial Biomass in Degraded Alpine Grasslands. Rangel. Ecol. Manag. 2019, 72, 396-404. [CrossRef]

76. Steffens, M.; Kölbl, A.; Totsche, K.U.; Kögel-Knabner, I. Grazing effects on soil chemical and physical properties in a semiarid steppe of Inner Mongolia. Geoderma 2008, 143, 63-72. [CrossRef]

77. Zhao, F.; Ren, C.; Shelton, S.; Wang, Z.; Pang, G.; Chen, J.; Wang, J. Grazing intensity influence soil microbial communities and their implications for soil respiration. Agric. Ecosyst. Environ. 2017, 249, 50-56. [CrossRef]

78. Zhou, G.; Zhou, X.; He, Y.; Shao, J.; Hu, Z.; Liu, R.; Zhou, H.; Hosseinibai, S. Grazing intensity significantly affects belowground carbon and nitrogen cycling in grassland ecosystems: A meta-analysis. Glob. Chang. Biol. 2017, 23, 1167-1179. [CrossRef]

79. Dlamini, P.; Chivenge, P.; Chaplot, V. Overgrazing decreases soil organic carbon stocks the most under dry climates and low soil pH: A meta-analysis shows. Agric. Ecosyst. Environ. 2016, 221, 258-269. [CrossRef]

80. Zhang, G.; Kang, Y.; Han, G.; Mei, H.; Sakurai, K. Grassland degradation reduces the carbon sequestration capacity of the vegetation and enhances the soil carbon and nitrogen loss. Acta Agric. Scand. Sect. B-Soil Plant Sci. 2011, 61, 356-364. [CrossRef]

81. Mchunu, C.; Chaplot, V. Land degradation impact on soil carbon losses through water erosion and $\mathrm{CO}_{2}$ emissions. Geoderma 2012, 177, 72-79. [CrossRef]

82. Yi, X.S.; Li, G.S.; Yin, Y.Y. The impacts of grassland vegetation degradation on soil hydrological and ecological effects in the source region of the Yellow River-A case study in Junmuchang region of Maqin country. Procedia Environ. Sci. 2012, 13, 967-981. [CrossRef]

83. Bertol, I.; Gomes, K.E.; Denardin, R.B.N.; Machado, L.A.Z.; Maraschin, G.E. Propriedades físicas do solo relacionadas a diferentes níveis de oferta de forragem numa pastagem natural. Pesqui. Agropecuária Bras. 1998, 33, 779-786.

84. Willatt, S.T.; Pullar, D.M. Changes in soil physical-properties under grazed pastures. Aust. J. Soil Res. 1984, 22, 343-348. [CrossRef]

85. Babel, W.; Biermann, T.; Coners, H.; Falge, E.; Seeber, E.; Ingrisch, J.; Willinghöfer, S. Pasture degradation modifies the water and carbon cycles of the Tibetan highlands. Biogeosciences 2014, 11, 6633-6656. [CrossRef]

86. Li, Z.; Wu, W.; Liu, X.; Fath, B.D.; Sun, H.; Liu, X.; Cao, J. Land use/cover change and regional climate change in an arid grassland ecosystem of Inner Mongolia, China. Ecol. Model. 2017, 353, 86-94. [CrossRef] 
87. Xie, Y.; Sha, Z. Quantitative analysis of driving factors of grassland degradation: A case study in Xilin River Basin, Inner Mongolia. Sci. World J. 2012, 2012, 14. [CrossRef]

88. Ludwig, J.A.; Wilcox, B.P.; Breshears, D.D.; Tongway, D.J.; Imeson, A.C. Vegetation patches and runoff-erosion as interacting ecohydrological processes in semiarid landscapes. Ecology 2005, 86, 288-297. [CrossRef]

89. Sun, L.; Yang, L.; Hao, L.; Fang, D.; Jin, K.; Huang, X. Hydrological effects of vegetation cover degradation and environmental implications in a semiarid temperate Steppe, China. Sustainability 2017, 9, 281. [CrossRef]

90. Mansour, K.; Mutanga, O.; Everson, T.; Adam, E. Discriminating indicator grass species for rangeland degradation assessment using hyperspectral data resampled to AISA Eagle resolution. ISPRS J. Photogramm. Remote Sens. 2012, 70, 56-65. [CrossRef]

91. Paudel, K.P.; Andersen, P. Assessing rangeland degradation using multi temporal satellite images and grazing pressure surface model in Upper Mustang, Trans Himalaya, Nepal. Remote Sens. Environ. 2010, 114, 1845-1855. [CrossRef]

92. Hoppe, F.; Kyzy, T.Z.; Usupbaev, A.; Schickhoff, U. Rangeland degradation assessment in Kyrgyzstan: Vegetation and soils as indicators of grazing pressure in Naryn Oblast. J. Mt. Sci. 2016, 13, 1567-1583. [CrossRef]

93. Wen, L.; Dong, S.; Li, Y.; Li, X.; Shi, J.; Wang, Y.; Liu, D.; Ma, Y. Effect of degradation intensity on grassland ecosystem services in the alpine region of Qinghai-Tibetan Plateau, China. PLoS ONE 2013, 8, e58432. [CrossRef]

94. Pielke, R.A.; Avissar, R.; Raupach, M.; Dolman, A.J.; Zeng, X.; Denning, A.S. Interactions between the atmosphere and terrestrial ecosystems: Influence on weather and climate. Glob. Chang. Biol. 1998, 4, 461-475. [CrossRef]

95. Pielke, R.A., Sr.; Adegoke, J.; BeltraáN-Przekurat, A.; Hiemstra, C.A.; Lin, J.; Nair, U.S.; Niyogi, D.; Nobis, T.E. An overview of regional land-use and land-cover impacts on rainfall. Tellus B Chem. Phys. Meteorol. 2007, 59, 587-601. [CrossRef]

96. Foley, J.A.; Costa, M.H.; Delire, C.; Ramankutty, N.; Snyder, P. Green surprise? How terrestrial ecosystems could affect earth's climate. Front. Ecol. Environ. 2003, 1, 38-44.

97. Feng, Q.; Ma, H.; Jiang, X.; Wang, X.; Cao, S. What has caused desertification in China? Sci. Rep. 2015, 5, 15998. [CrossRef]

98. Bakker, E.S.; Ritchie, M.E.; Olff, H.; Milchunas, D.G.; Knops, J.M. Herbivore impact on grassland plant diversity depends on habitat productivity and herbivore size. Ecol. Lett. 2006, 9, 780-788. [CrossRef]

99. Altesor, A.; Piñeiro, G.; Lezama, F.; Jackson, R.B.; Sarasola, M.; Paruelo, J.M. Ecosystem changes associated with grazing in subhumid South American grasslands. J. Veg. Sci. 2006, 17, 323-332. [CrossRef]

100. Lezama, F.; Baeza, S.; Altesor, A.; Cesa, A.; Chaneton, E.J.; Paruelo, J.M. Variation of grazing-induced vegetation changes across a large-scale productivity gradient. J. Veg. Sci. 2014, 25, 8-21. [CrossRef]

101. Eldridge, D.J.; Poore, A.G.; Ruiz-Colmenero, M.; Letnic, M.; Soliveres, S. Ecosystem structure, function, and composition in rangelands are negatively affected by livestock grazing. Ecol. Appl. 2016, 26, 1273-1283. [CrossRef]

102. Cingolani, A.M.; Noy-Meir, I.; Díaz, S. Grazing effects on rangeland diversity: A synthesis of contemporary models. Ecol. Appl. 2005, 15, 757-773. [CrossRef]

103. Milchunas, D.G.; Sala, O.E.; Lauenroth, W. A generalized model of the effects of grazing by large herbivores on grassland community structure. Am. Nat. 1988, 132, 87-106. [CrossRef]

104. Deng, L.; Shangguan, Z.P. Species composition, richness and aboveground biomass of natural grassland in Hilly-Gully Regions of the Loess Plateau. China J. Integr. Agric. 2014, 13, 2527-2536. [CrossRef]

105. Soriano, A.; León, R.J.C.; Sala, O.E.; Lavado, R.S.; Deregibus, V.A.; Cahuepé, M.A.; Scaglia, O.A.; Velazquez, C.A.; Lemcoff, J.H. Río de la Plata grasslands. In Ecosystems of the World 8A. Natural Grasslands. Introduction and Western Hemisphere; Coupland, R.T., Ed.; Elsevier: New York, NY, USA, 1992; pp. 367-407.

106. Overbeck, G.E.; Müller, S.C.; Fidelis, A.; Pfadenhauer, J.; Pillar, V.D.; Blanco, C.C.; Boldrini, I.I.; Both, R.; Forneck, E.D. Brazil's neglected biome: The South Brazilian Campos. Perspect. Plant Ecol. Evol. Syst. 2007, 9, 101-116. [CrossRef]

107. Bilenca, D.; Miñarro, F. Identificación de Áreas Valiosas de Pastizal (AVPs) en las Pampas y Cam-pos de Argentina, Uruguay y sur de Brasil; Fundación Vida Silvestre Argentina: Buenos Aires, Argentina, 2004; p. 352.

108. Fonseca, C.R.; Guadagnin, D.L.; Emer, C.; Masciadri, S.; Germain, P.; Zalba, S.M. Invasive alien plants in the Pampas grasslands: A tri-national cooperation challenge. Biol. Invasions 2013, 15, 1751-1763. [CrossRef]

109. Guido, A.; Varela, R.D.; Baldassini, P.; Paruelo, J. Spatial and temporal variability in aboveground net primary production of Uruguayan grasslands. Rangel. Ecol. Manag. 2014, 67, 30-38. [CrossRef] 
110. Medeiros, R.B.; Pillar, V.D.; Reis, J.C.L. Expansão de Eragrostis plana Ness (capim-annoni-2), no Rio Grande do Sul e indicativos de controle. In Reunión del grupo técnico regional del Cono Sur en mejoramiento y utilización de los recursos forrajeros del área tropical y subtropical, Grupo Campos, 20. Salto, Uruguay, 2004; Regional Norte de la Universidad de la República: Salto, Uruguay, 2004; pp. 208-211.

111. Jaurena, M.; Bentancur, O.; Ayala, W.; Rivas, M. Especies indicadoras y estructura de praderas naturales de basalto con cargas contrastantes de ovinos. Agrociencia Urug. 2011, 15, 103-114.

112. Sala, O.E.; Oesterheld, M.; León, R.J.C.; Soriano, A. Grazing effects upon plant community structure in subhumid grasslands of Argentina. Vegetatio 1986, 67, 27-32.

113. Focht, T.; Medeiros, R.B.D. Prevention of natural grassland invasion by Eragrostis plana Nees using ecological management practices. Rev. Bras. Zootec. 2012, 41, 1816-1823. [CrossRef]

114. Lin, L.; Li, Y.K.; Xu, X.L.; Zhang, F.W.; Du, Y.G.; Liu, S.L.; Gou, X.W.; Cao, G.M. Predicting parameters of degradation succession processes of Tibetan Kobresia grasslands. Solid Earth 2015, 6, 1237-1246. [CrossRef]

115. Liu, B.; You, G.; Li, R.; Shen, W.; Yue, Y.; Lin, N. Spectral characteristics of alpine grassland and their changes responding to grassland degradation on the Tibetan Plateau. Environ. Earth Sci. 2015, 74, 2115-2123. [CrossRef]

116. Geerken, R.; Ilaiwi, M. Assessment of rangeland degradation and development of a strategy for rehabilitation. Remote Sens. Environ. 2004, 90, 490-504. [CrossRef]

117. Hao, C.; $\mathrm{Wu}, \mathrm{S}$. The effects of land-use types and conversions on desertification in Mu Us Sandy Land of China. J. Geogr. Sci. 2006, 16, 57-68. [CrossRef]

118. Baldi, G.; Paruelo, J.M. Land-use and land cover dynamics in South American temperate grasslands. Ecol. Soc. 2008, 13. [CrossRef]

119. Vega, E.; Baldi, G.; Jobbagy, E.G.; Paruelo, J. Land use change patterns in the Río de la Plata grasslands: The influence of phytogeographic and political boundaries. Agric. Ecosyst. Environ. 2009, 134, 287-292. [CrossRef]

120. Mugerwa, S.; Emmanuel, Z. Drivers of grassland ecosystems' deterioration in Uganda. Appl. Sci. Rep. 2014, $2,103-111$.

121. Li, C.; de Jong, R.; Schmid, B.; Wulf, H.; Schaepman, M.E. Spatial variation of human influences on grassland biomass on the Qinghai-Tibetan plateau. Sci. Total Environ. 2019, 665, 678-689. [CrossRef] [PubMed]

122. McGranahan, D.A.; Engle, D.M.; Wilsey, B.J.; Fuhlendorf, S.D.; Miller, J.R.; Debinski, D.M. Grazing and an invasive grass confound spatial pattern of exotic and native grassland plant species richness. Basic Appl. Ecol. 2012, 13, 654-662. [CrossRef]

123. Liu, J.; Xu, X.; Shao, Q. Grassland degradation in the "Three-River Headwaters" region, Qinghai Province. J. Geogr. Sci. 2008, 18, 259-273. [CrossRef]

124. Zhao, Y.; He, C.; Zhang, Q. Monitoring vegetation dynamics by coupling linear trend analysis with change vector analysis: A case study in the Xilingol steppe in northern China. Int. J. Remote Sens. 2012, 33, 287-308. [CrossRef]

125. Ho, P.; Azadi, H. Rangeland degradation in North China: Perceptions of pastoralists. Environ. Res. 2010, 110, 302-307.

126. Miehe, S.; Kluge, J.; Von Wehrden, H.; Retzer, V. Long-term degradation of Sahelian rangeland detected by 27 years of field study in Senegal. J. Appl. Ecol. 2010, 47, 692-700. [CrossRef]

127. Guido, A.; Vélez-Martin, E.; Overbeck, G.E.; Pillar, V.D. Landscape structure and climate affect plant invasion in subtropical grasslands. Appl. Veg. Sci. 2016, 19, 600-610. [CrossRef]

128. Semmartin, M.; Di Bella, C.; de Salamone, I.G. Grazing-induced changes in plant species composition affect plant and soil properties of grassland mesocosms. Plant Soil 2010, 328, 471-481. [CrossRef]

129. Pickup, G. Estimating the effects of land degradation and rainfall variation on productivity in rangelands: An approach using remote sensing and models of grazing and herbage dynamics. J. Appl. Ecol. 1996, 33, 819-832. [CrossRef]

130. Snyman, H.A. Soil seed bank evaluation and seedling establishment along a degradation gradient in a semi-arid rangeland. Afr. J. Range Forage Sci. 2004, 21, 37-47. [CrossRef]

131. Vieira, M.D.S.; Bonilha, C.L.; Boldrini, I.I.; Overbeck, G.E. The seed bank of subtropical grasslands with contrasting land-use history in southern Brazil. Acta Bot. Braz. 2015, 29, 543-552. [CrossRef] 
132. Andrade, B.O.; Koch, C.; Boldrini, I.I.; Vélez-Martin, E.; Hasenack, H.; Hermann, J.M.; Kollman, J.; Pillar, V.D.; Overbeck, G.E. Grassland degradation and restoration: A conceptual framework of stages and thresholds illustrated by southern Brazilian grasslands. Nat. Conserv. 2015, 13, 95-104. [CrossRef]

133. Chaneton, E.J.; Perelman, S.B.; Omacini, M.; Leon, R.J.C. Grazing, environmental heterogeneity, and alien plant invasions in temperate Pampa grasslands. Biol. Invasions 2002, 4, 7-24. [CrossRef]

134. Altesor, A.; López-Marsico, L.; Paruelo, J. (Eds.) Bases Ecológicas y Tecnológicas Para el Manejo de Pastizales II; Serie FPTA-INIA (69); INIA: Montevideo, Uruguay, 2019; p. 167.

135. Porensky, L.M.; Mueller, K.E.; Augustine, D.J.; Derner, J.D. Thresholds and gradients in a semi-arid grassland: Long-term grazing treatments induce slow, continuous and reversible vegetation change. J. Appl. Ecol. 2016, 53, 1013-1022. [CrossRef]

136. Oesterheld, M.; Semmartin, M. Impact of grazing on species composition: Adding complexity to a generalized model. Austral Ecol. 2011, 36, 881-890. [CrossRef]

137. Wang, Z.; Zhang, Y.; Yang, Y.; Zhou, W.; Gang, C.; Zhang, Y.; Li, J.; An, R.; Wang, K.; Odeh, I.; et al. Quantitative assess the driving forces on the grassland degradation in the Qinghai-Tibet Plateau, in China. Ecol. Inform. 2016, 33, 32-44. [CrossRef]

138. Davidowitz, G. Does precipitation variability increase from mesic to xeric biomes? Glob. Ecol. Biogeogr. 2002, 11, 143-154. [CrossRef]

139. Whitford, W.G. Ecology of Desert Systems. J. Mammal. 2002, 84, 1122-1124.

140. Van Etten, E.J. Inter-annual rainfall variability of arid Australia: Greater than elsewhere? Aust. Geogr. 2009, 40, 109-120. [CrossRef]

141. Le Houérou, H.N. A probabilistic approach to assessing arid rangelands' productivity, carrying capacity and stocking rates. In Drylands: Sustainable Use of Rangelands into the Twenty First Century; Squires, V.R., Sidahmed, A.E., Eds.; IFAD: Rome, Italy, 1998; pp. 159-172.

142. Wiegand, T.; Snyman, H.A.; Kellner, K.; Paruelo, J.M. Do grasslands have a memory: Modeling phytomass production of a semiarid South African grassland. Ecosystems 2004, 7, 243-258. [CrossRef]

143. Sloat, L.L.; Gerber, J.S.; Samberg, L.H.; Smith, W.K.; Herrero, M.; Ferreira, L.G.; Godde, C.M.; West, P.C. Increasing importance of precipitation variability on global livestock grazing lands. Nat. Clim. Chang. 2018, 8, 214. [CrossRef]

144. Ellis, J.E.; Swift, D.M. Stability of African pastoral ecosystems: Alternate paradigms and implications for development. Rangel. Ecol. Manag. J. Range Manag. Arch. 1998, 41, 450-459. [CrossRef]

145. Briske, D.D.; Zhao, M.; Han, G.; Xiu, C.; Kemp, D.R.; Willms, W.; Havstad, K.; Kang, L.; Wang, Z.; Wu, J.; et al. Strategies to alleviate poverty and grassland degradation in Inner Mongolia: Intensification vs. production efficiency of livestock systems. J. Environ. Manag. 2015, 152, 177-182. [CrossRef] 